To appear in Folia Linguistica 2020; 54(1): 133-166

https://doi.org/10.1515/flin-2020-2029

Tatiana Nikitina \& Alexandra Vydrina

\title{
Reported speech in Kakabe: Loose syntax with flexible indexicality
}

\begin{abstract}
Mainstream approaches to the typology of reported discourse have been based on the notion of a direct-indirect continuum: reported speech constructions are traditionally analyzed as conforming to or deviating from the "ideals" of European direct and indirect speech. This study argues that continuum-based approaches fail to distinguish between two dimensions of variation that are systematically discriminated in a number of African languages and should therefore be treated separately. First, different constructions can be recruited for speech reporting, ranging from paratactic to subordinate structures. Second, languages differ in the way pronouns in speech reports are interpreted. In European languages two different deictic strategies are associated with different syntactic types of speech report ("indirect" and "direct" deixis is correlated with subordination and parataxis, respectively). In Kakabe, we argue, the choice of pronominal values is independent of the construction's syntax. Dissociating the construction's structural properties from the behavior of indexicals allows us to describe the Kakabe strategies of speech reporting, as well as account for the seemingly puzzling behavior of reported commands. Our data shows that speech reporting strategies of Kakabe should be treated as a type in its own right: a type characterized by loose syntax and flexible pronominal indexicality.
\end{abstract}

Keywords: reported speech, syntax, Mande languages, indexicality, personal pronouns 


\section{Reported speech in Kakabe: \\ Loose syntax with flexible indexicality}

\section{Introduction ${ }^{1}$}

Reported speech is a universal feature of narrative discourse, and all languages have one or more ways of expressing it. Yet the grammar of speech reporting remains very poorly studied, and research on speech reporting tends to focus on the question of the universality of the distinction between European-style direct and indirect speech (Coulmas 1986; Roncador 1988; De Roeck 1994; Güldemann and Roncador 2002; Aikhenvald 2008; Nikitina 2012a, inter alia). Little is known about the typology of reported speech constructions besides the fact that languages may "deviate from the traditional ideals of 'direct' and 'indirect' speech" in a number of ways (Evans 2013: 67). Attempts to typologize the "deviating" types, however, have been largely restricted to placing speech-reporting constructions on a continuum stretching from prototypical direct to prototypical indirect reporting - a continuum that presupposes the primacy and underlying universality of the European construction types (Güldemann 2008; Evans 2013). The reality, however, is more complex than suggested by the dichotomy-based continua as properties of reported speech constructions vary on multiple independent dimensions that cannot all be subsumed under a single parameter corresponding to some sort of "degree of (in)directness" (Nikitina \& Bugaeva forthc.).

In this paper we argue, based on data from Kakabe (Central Mande; Guinea), ${ }^{2}$ that at least two dimensions of variation should be distinguished: the syntax of speech-reporting constructions, or the way speech reports are structurally integrated into their environment, and language-specific patterns of indexicality, or the way deictic elements are interpreted in the context of reported speech. This conclusion is supported by what from a European point of view is a fundamental discrepancy between the syntax of reported speech and the way pronouns are used to refer to participants of the reported speech situation. ${ }^{3}$ The pronouns allow for two different interpretations: they can be assigned referents in the context of the current speech situation or in the context of the reported speech situation. In other words, they allow for either "direct" or "indirect" interpretation, shifting their reference freely from current event participants to participants in the reported speech event. Crucially, the difference in interpretation does not correspond systematically to a difference in the construction's syntax: on both interpretations, the reported speech construction behaves as if it

\footnotetext{
${ }^{1}$ This project has received funding from the European Research Council (ERC) under the European Union's Horizon 2020 research and innovation programme (grant agreement No 758232).

${ }^{2}$ Kakabe is a little-researched Mande language spoken in the Republic of Guinea, by approximately 50000 speakers. The study is based on a corpus of over 12 hours of conversation and storytelling that were recorded, transcribed and annotated between 2009 and 2016. The corpus is available in the ELAR archive in the Kakabe collection (https://elar.soas.ac.uk/Collection/MPI43300). For this study, we extracted from the Kakabe corpus a database of 679 clauses conveying reported discourse.

${ }^{3}$ We focus on pronouns and do not treat temporal or spatial deixis, since we do not have enough information on the ways temporal and spatial adverbials behave outside reported speech constructions, and in particular, on whether or not Kakabe has genuinely deictic temporal and spatial adverbials (as opposed to adverbials with a contextually shiftable interpretation). We briefly return to this problem for temporal adverbs in Section 3.1.
} 
involved direct speech - structurally, the quotation part is not embedded and is only loosely related to its context.

The discrepancy between the flexible pronominal behavior and the rigid syntax of reported speech suggests that the two dimensions are independent. While the syntax of the construction corresponds to the ideal type of European direct speech, patterns of indexicality fluctuate between the direct and the indirect prototypes, undermining the usefulness of the continuum-based approach for detailed description of language-specific patterns. While we focus here on describing reported speech constructions of Kakabe, we believe that the same pattern, with minor variations, is widespread across West Africa, and deserves being treated as a stable type in its own right.

The paper is organized as follows. We first describe the basic reported speech construction of Kakabe and survey its syntactic behavior, arguing that it shares many structural properties with European-style prototypical direct speech (Section 2). We then show that the indexicality of speech reports is systematically flexible, and pronouns can be assigned referents based on participant roles in either the current or the reported speech situation (Section 3). Crucially, as shown in Section 4, there is no systematic correlation between the way pronouns are interpreted and the way reported speech is integrated syntactically into surrounding discourse: "indirect" pronominal deixis, in particular, freely combines with syntactic features suggesting that the speech report is non-subordinated. We discuss implications of this pattern for the typology of speech reporting constructions and the analysis of indexicals in Section 5, and draw further conclusions in Section 6.

\section{The syntax of reported speech in Kakabe}

\subsection{How reported speech is introduced}

There are two major strategies for introducing reported speech in Kakabe: it can be introduced by a speech verb or by a quotative marker (and the two can also be combined). Reported speech also need not be introduced overtly, especially in the context of a dialogue. We describe these cases in more detail in the rest of this section.

The preferred reported speech construction involves a speech verb: either a regular one, such as $f \prime \prime$ 'say', as in (1), or the defective verb $k o ́$, as in (2). ${ }^{4}$ Unlike regular verbs, $k o ́$ appears without any auxiliary-like element, cf. the potential marker si in (1) and the absence of any auxiliary-like marker in (2) ${ }^{5}$. Yet it still behaves like a verb in licensing arguments, e.g. in (2), it appears with a subject. ${ }^{6}$

\footnotetext{
${ }^{4}$ The verb kó has a lexical high tone but is realized with a low tone after a full NP subject.

${ }^{5}$ Kakabe is a tonal language with the rigid S-(Aux)-O-V-X word order typical of Mande languages (where X stands for any oblique argument or adjunct, Nikitina 2009, 2019):

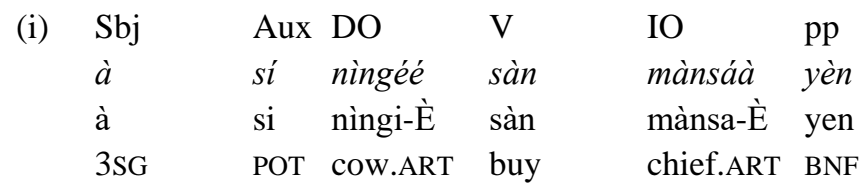

'He will buy a cow for the chief.'

${ }^{6}$ We will later see examples where it introduces an addressee argument, e.g. (6) or (31a), and is modified by an adjunct, e.g. (33).
} 
(1) ì sáà fò ì lá wùléè mà à bìn à bìn

ì si-à fó ì la wùlu-È ma à bìta à bìta

2SG POT-3SG say 2SG POSS dog-ART to 3SG catch 3SG catch

'You say to your dog: Catch it, catch it!'

(KKEC_AV_CONV_131207_TALK05_133)

(2) à kó ňdè kánpátán bélé ǹ bòlò

à kó ňdè kànpatan béle ̀̀ bólo

3SG say $1 \mathrm{SG} . \mathrm{LG}$ wing be.NEG $1 \mathrm{SG}$ hand

'He said: I don't have wings'.

(KKEC_AV_CONV_131207_TALK05_277)

Apart from being used as a speech-introducing verb, albeit a defective one, $k o ́$ is also attested in the function of a quotative marker. When used in that function, it cannot take arguments, and the speaker's identity must be inferred from the larger context. In (3), for example, kó is used on its own, without a subject (cf. 2). Since verbs do not allow subjects to be omitted, we treat such uses as involving a quotative marker, and this difference is reflected in the different glossing of kó in (3) as compared to (2).

$\begin{array}{lllll}\text { (3) kó } & \text { ì níi } & \text { bààbà } & \text { kìlì } \\ \text { kó } & \text { ì } & \text { ni-ì } & \text { bàaba } & \text { kíli } \\ \text { QU } & \text { 2SG } & \text { SBJV-2SG } & \text { father } & \text { call }\end{array}$

'[He] said: Call your father!'

(KKEC_AV_NARR_131227_AK3_163)

As a quotative marker, kó can freely combine with speech verbs, such as the verb f' 'say' in (4).

$\begin{array}{llllllll}\text { (4) ì náà } & \text { f́ } & \text { à } & \text { yèn kó } & \text { ǹ } & \text { báb } & \text { básè } & \text { sòtòn } \\ \text { ì ni-à } & \text { f́́ } & \text { à } & \text { yen kó } & \text { ǹ } & \text { báti } & \text { bási-È } & \text { sòton } \\ \text { 2SG SBJV-3SG } & \text { say } & \text { 3SG } & \text { BNF QU } & \text { 1SG PFV.OF } & \text { medicine-ART } & \text { get }\end{array}$

'You ${ }_{i}$ should tell him: $I_{i}$ have found the medicine.'

(KKEC_AV_NARR_131227_AK3_163)

The quotative function of kó most likely developed from its use as a speech verb, and speech verbs cognate with kó can be found in other Mande languages. This development is well attested in Mande (Idiatov 2010) and across languages (Lord 1993; Klamer 2000), and it is described by Heine \& Kuteva (2000) in terms of grammaticalization from verbal to quotative use and then to uses associated with complementizer and other subordinating functions. Only the verbal and the quotative uses are attested in Kakabe.

The two diachronically related functions co-exist and can be combined in the same sentence, resulting in examples where kó appears twice, once as a quotative marker and once 
as a speech-introducing verb, as in (5)-(6). Note again that the difference between the verb and the quotative marker is reflected in our glossing.
(5) yćgénnè kò kó ń dònídè yége-nden-È kó kó ǹ dònidè 'The little fishi said: Take mei to the road.'
(6) àn kó à mà kó jàbét lè ànu kó à ma kó jàbet lè 3PL say 3SG to QU diabetis FP 'They told her that it was diabetes.' kílà là fish-DIM-ART say QU 1SG take EMPH road-ART OBL (KKEC_AV_CONV_131207_TALK05_291)

(KKEC_AV_NARR_131227_AK3_147)

Both speech verbs and the quotative marker always precede the speech report, i.e. the order of the two parts of the construction cannot be reversed, cf. (7a) vs. (7b) for regular speech verbs and (8a) vs. (8b) for the defective speech verb kó. Other ordering options are also not allowed, e.g. no example is attested where one part of the construction would be inserted into the other.

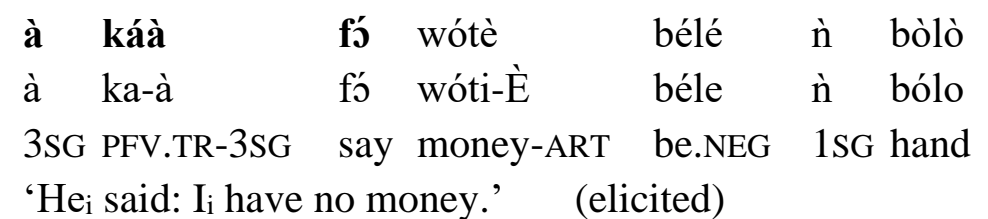

$\begin{array}{llllllll}(7 \mathrm{~b}) * & \text { wótè } & \text { béle } & \text { ǹ } & \text { bólo } & \text { à } & \text { káà } & \text { f́ } \\ \text { wóti-È } & \text { béle } & \text { ǹ } & \text { bólo } & \text { à } & \text { ka-à } & \text { f́́ } \\ \text { money-ART } & \text { be.NEG } & \text { 1SG hand } & \text { 3SG } & \text { PFV.TR-3SG } & \text { say }\end{array}$

$\begin{array}{llllll}\text { (8a) à kó wótè } & \text { bélé } & \text { ǹ bòlò } \\ \text { à } \quad \text { kó } & \text { wóti-E } & \text { béle } & \text { ̀̀ bólo } \\ \text { 3SG say money-ART } & \text { be.NEG } & \text { 1SG hand } \\ \text { 'He } & \text { said: } \mathrm{I}_{\mathrm{i}} \text { have no money.' } & \text { (elicited) }\end{array}$

$\begin{array}{lllllll}(8 \mathrm{~b}) * & \text { wótè } & \text { bélé } & \text { ǹ } & \text { bóló } & \text { à } & \text { kó } \\ \text { wóti-È } & \text { béle } & \text { ̀̀ } & \text { bólo } & \text { à } & \text { kó } \\ \text { money-ART } & \text { be.NEG } & \text { 1SG hand } & \text { 3SG } & \text { say }\end{array}$

Like direct speech across languages, and unlike prototypical indirect speech, reported speech in Kakabe need not be introduced by a verb of speaking, and it sometimes appears without any licensor (cf. D’Arcy 2015; Spronck 2017; Spronck \& Nikitina 2019). In (9), the portion in bold is only interpreted as reported speech based on context. In (10), too, whereas the speech of the first participant is introduced by the verb kó, the answer of the second participant appears, in the context of a dialogue, without any quotative marker or verb of speaking: 


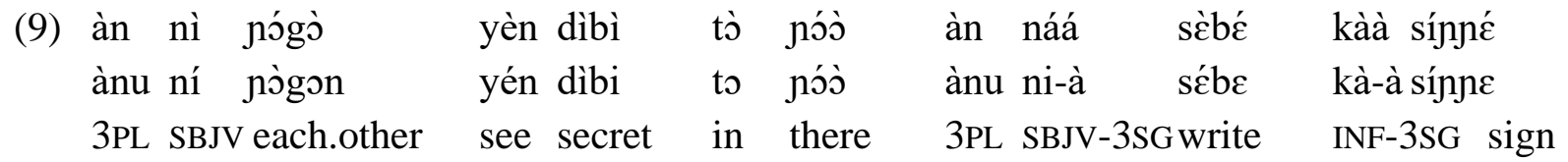

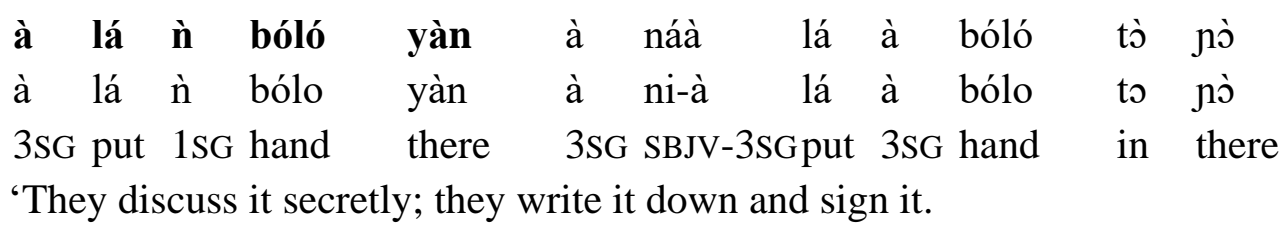

Give it to me! -He gives it to him.'

(KKE-C_2018-01-16_CAMPAGNE-1_278)

$\begin{array}{lllllll}\text { (10) à } & \text { kó } & \text { mà bátáà } & \text { lòn } & \text { mín káà } & \text { nìmì } \\ \text { à } & \text { kó } & \text { mà } & \text { báti-à } & \text { lón } & \text { mín ka-à } & \text { ními } \\ \text { 3SG } & \text { say } & 1 \text { PL } & \text { PFV.OF-3SG } & \text { know } & \text { REL PFV.TR-3SG } & \text { eat }\end{array}$

$\begin{array}{lllll}\text { jó } & \text { wó } & \text { tí } & \text { ̀̀ } & \text { náfàlgé } \\ \text { ว̀́ } & \text { wò } & \text { báti } & \text { ǹ } & \text { lafàlge } \\ \text { no } & \text { 2PL } & \text { PFV.TR } & \text { 1SG } & \text { deceive }\end{array}$

'He said: We know who has eaten it. - No! You have deceived me.'

(KKE-C_2013-12-20_KP_TALE-3_269)

\subsection{Reported speech accommodates interjections and address terms}

As typical of direct speech cross-linguistically, and atypical of European-style "canonical" indirect speech (as defined, for example, by Evans 2013), reported speech in Kakabe accommodates interjections and address terms.

(11) kó é yááyè ì bí ǹ dàmùlà fénnà?

kó é yáaye ì bi ̀̀ dámu-la fénnà

QU hey aunt 2SG be 1SG eat-GER why

'Hei said: Hey! Aunt! Why do you want to eat me ${ }_{i}$ ?'

(KKEC_AV_NARR_131227_AK1_20)

The reason interjections and address terms are commonly excluded from prototypical indirect speech has to do with the subordinate status of indirect speech reports in European languages: it is common for subordinate clauses to be structurally reduced, whereas interjections and address terms normally function as sentence-level adjuncts. In Kakabe, too, they seem to be adjoined very high up in the sentence structure. Like other high-adjoined elements, such as fronted adverbials, they are, for example, often followed by a quotative marker, as in (12a). This sometimes results in multiple quotative markers introducing different parts of a speech report, as in (12b). 
(KKEC_AV_CONV_131227_AK3_132)

(12b)

$\begin{array}{llllll}\text { kó bààbà } & \text { kó } & \text { ǹ bá } & \text { gbàndíya } \\ \text { kó } & \text { bàaba } & \text { kó } & \text { ǹ báti } & \text { gbàndiya } \\ \text { QU father } & \text { QU } & \text { 1SG PFV.OF } & \text { fall.ill }\end{array}$

'She i said: Father, $\mathrm{I}_{\mathrm{i}}$ am ill.'

(KKEC_AV_NARR_131227_AK3_131)

\subsection{Absence of prosodic integration}

Reported speech need not be integrated prosodically into the surrounding discourse. ${ }^{7}$ The systematic absence of prosodic integration is reflected in two different phenomena.

One is the tendency of the two parts of the speech reporting construction to be separated by a downdrift break. Kakabe has downdrift, or automatic downstep (for a discussion of terminology, see Connell and Ladd 1990; Yip 2002: 147ff): in a sequence of alternating $\mathrm{H}$ and $\mathrm{L}$ tones, every next $\mathrm{H}$ is pronounced lower than the preceding one. The domain of downdrift in Kakabe is the Intonation Phrase (for more details on downdrift in Kakabe, see Vydrina 2017: 354-358). The extract in (13) illustrates an Intonation Phrase consisting of two coordinated sentences, united by one downdrift pattern (Figure 1).

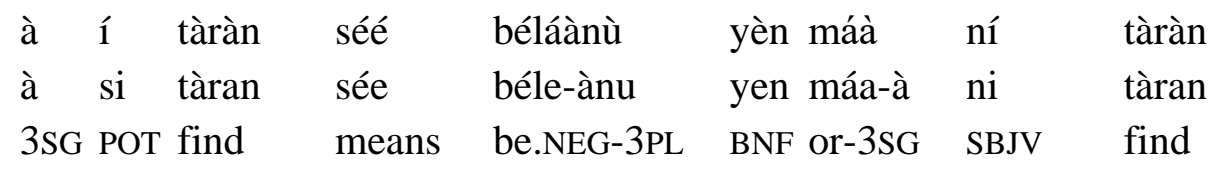

$\begin{array}{lllll}\text { séé } & \text { béláàn } & \text { ná } & \text { kàyénì } & \text { yén } \\ \text { sée } & \text { béle-ànu } & \text { la } & \text { kàyi-Ė-nu } & \text { yen } \\ \text { means } & \text { be.NEG-3PL } & \text { POSS } & \text { man-ART-PL } & \text { BNF }\end{array}$

'Is it that they have no money or is it because their husbands have no money [that they do not buy any clothes for the holidays]?'

(KKEC_AV_CONV_131207_TALK03_167)

\footnotetext{
${ }^{7}$ See Malibert \& Vanhove (2015) for a typology of patterns of prosodic integration of speech reports; Podlesskaya (2018) for a discussion of prosodic (non-)integration of direct speech in colloquial Russian.
} 


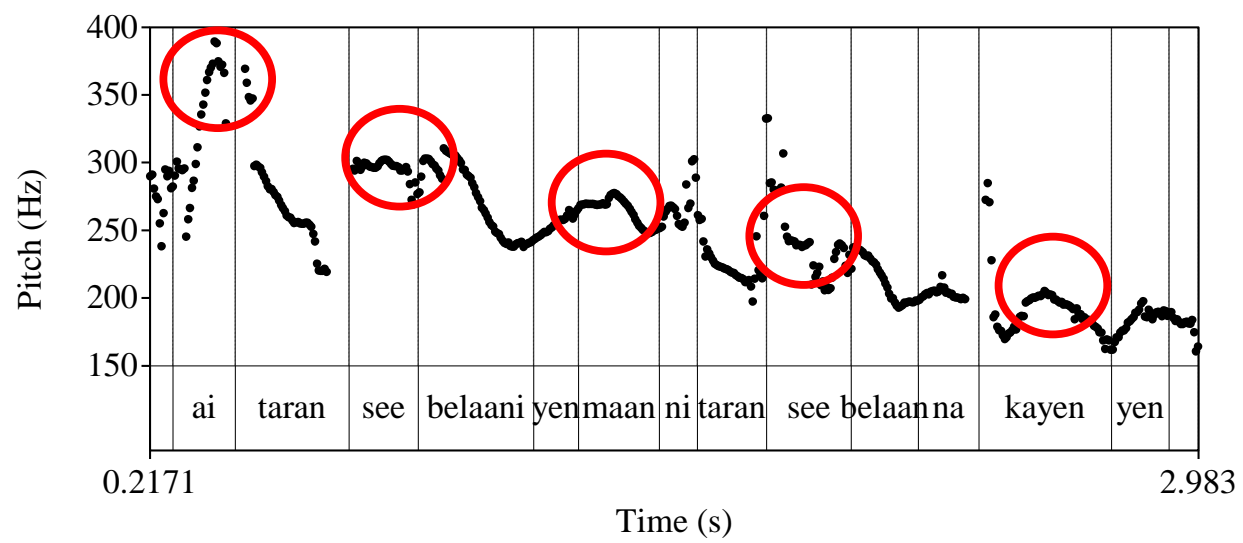

Figure 1. Pitch curve illustrating downdrift across one Intonation Phrase

The two parts of the speech reporting construction need not form an Intonation Phrase, i.e. their integration into one prosodic unit is optional. In (14), the two parts of the construction form an Intonation Phrase, and the first $\mathrm{H}$ of the speech report - the first $\mathrm{H}$ of the 1SG pronoun ńdé - is downdrifted with respect to the $\mathrm{H}$ in the preceding clause (Figure 2):

$$
\begin{aligned}
& \text { kálá yáá fỏlà ńdé `lé `yáá lábòrìlà } \\
& \text { kála bi-à fó-la ňdè lè bi-à labòri-la } \\
& \text { every be-3SG say-GER 1SG.LG FP be-3SG run-GER }
\end{aligned}
$$

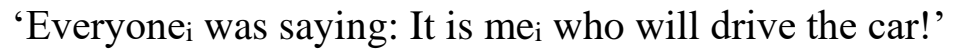

(KKEC_AV_NARR_150124_AK2_201)

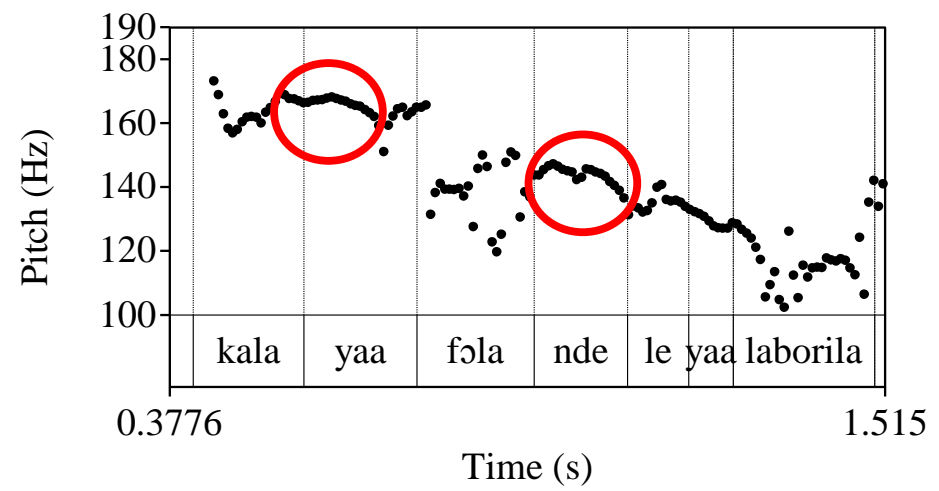

Figure 2. Pitch curve illustrating the integration of speech report into one Intonation Phrase with the speech-event clause

In (15), the speech report is separated from the speech-event introducing clause by a clear downdrift break: the $\mathrm{H}$ tone at the beginning of the clause is realized at the same level as (or even slightly higher than) the first $\mathrm{H}$ of the preceding speech-event introducing clause (Figure $3)$. 


$$
\begin{array}{llllllllll}
\text { ànì } & \text { yáá } & \text { fólá } & \text { lè } & \text { kó } & \text { ń } & \text { sáà } & \text { wà } & \text { swàré } & \text { tò } \\
\text { ànu } & \text { bi-à } & \text { fó-la } & \text { lè } & \text { kó } & \text { ǹ } & \text { si-à } & \text { wá } & \text { swàre-È } & \text { to } \\
\text { 3PL } & \text { be-3SG } & \text { say-GER } & \text { FP } & \text { QU } & \text { 1SG } & \text { POT-3SG } & \text { go } & \text { party-ART } & \text { to }
\end{array}
$$

'They say: I will go to the party.' (KKEC_AV_CONV_131207_TALK03_205)

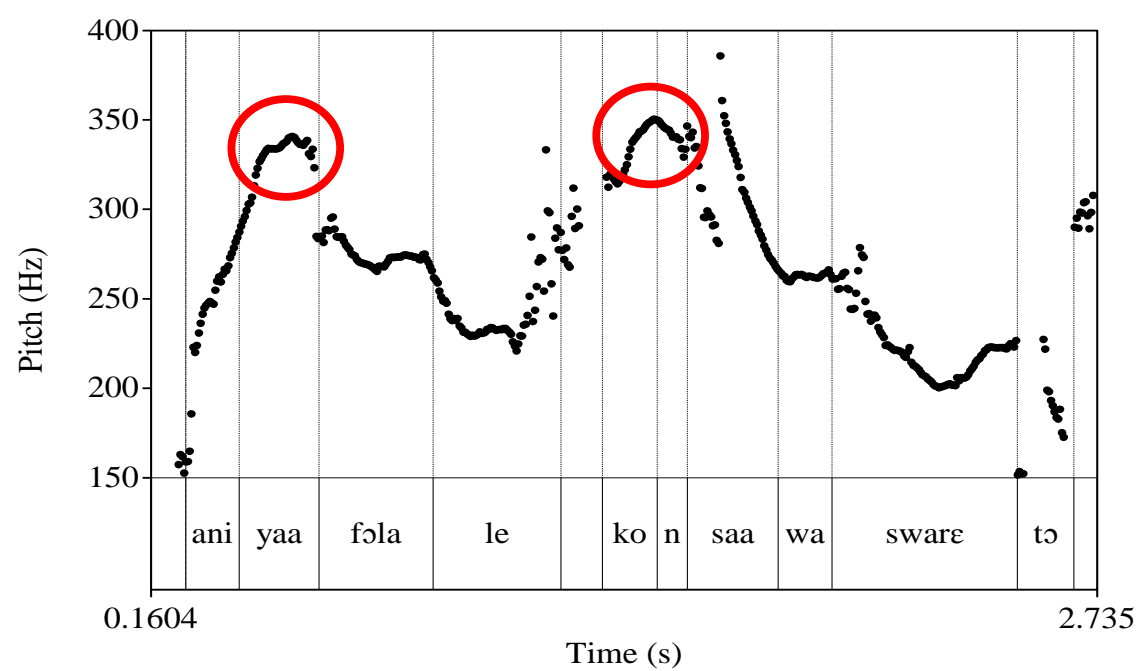

Figure 3. Pitch curve showing prosodically autonomous realization of speech report (absence of downdrift)

In (16)-(17), too, a downdrift break separates the two parts of the speech reporting construction: the $\mathrm{H}$ on the address term néc̀nè 'mother' in (16) and on the negation word ḿm 'no' in (17) are realized on the same level as the $\mathrm{H}$ on the subject of the speech-event introducing part (Figures 4-5):

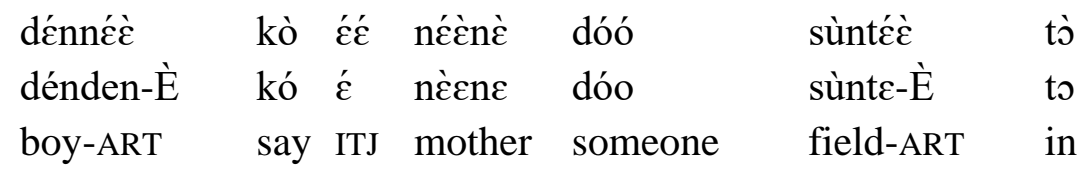

'The boy said: Eh, Mother, there is somebody in the field.'

(KKEC_AV_CONV_131207_TALK05_284)

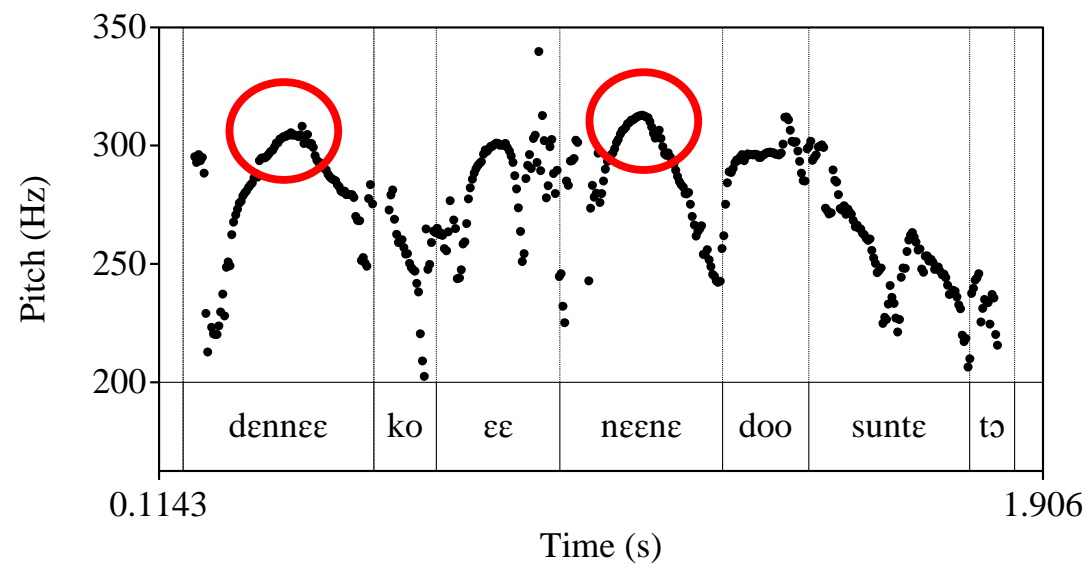

Figure 4. Pitch curve showing prosodically autonomous realization of speech report (absence of downdrift) 


$\begin{array}{llllllll}\text { kàyéé } & \text { náá } & \text { fò món ì bél } & \text { tágálá } & \text { bìi } & \text { yè } \\ \text { kàyi-È } & \text { ni-à } & \text { fó } & \text { ḿm ì bélé } & \text { tága-la } & \text { bìi } & \text { yè } \\ \text { man-ART } & \text { SBJV-3SG } & \text { say } & \text { no } & \text { 2SG be.NEG } & \text { go-GER } & \text { today } & \text { FP.C }\end{array}$

'The man says: No, you will not go today.'

(KKEC_AV_CONV_131207_TALK03_204)

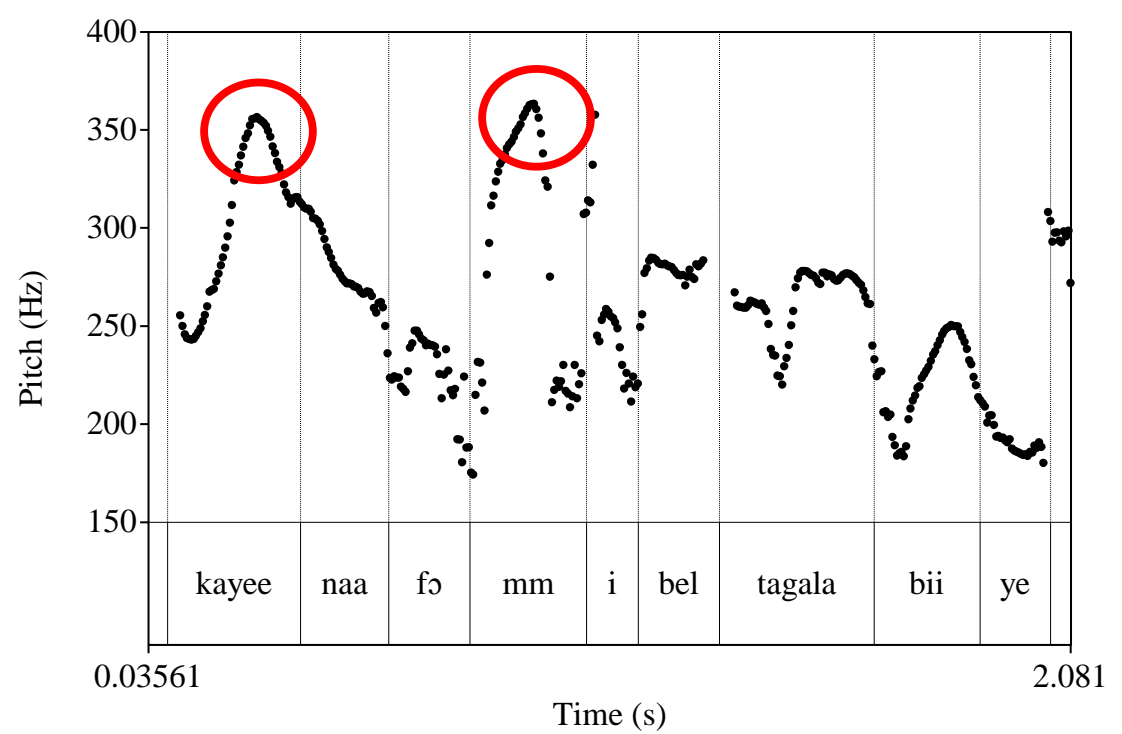

Figure 5. Pitch curve showing prosodically autonomous realization of speech report (absence of downdrift)

The downdrift break between the two parts of the speech-reporting construction suggests that the speech report is prosodically autonomous. We will later show (Section 4.3) that this autonomy is independent of the pronominal strategy used within the report: it characterizes reports with both "direct" and "indirect" pronominal deixis.

The other piece of evidence for the prosodic autonomy of reported speech comes from the interaction of its prosody with negation. In Kakabe, different boundary tones appear in different syntactic environments at the end of the Intonation Phrase. The Low boundary tone L\% - appears in affirmative and interrogative clauses, and is realized as a Low tone on the last syllable of the Intonation phrase. For example, in (18a) and (18b) L\% is triggered by two different kinds of question.

$\begin{array}{llllll}\text { (18a) wò sí mògó } & \text { kàràndén } & \text { sòtò } & \text { kóóbèn } \\ \text { wò } & \text { si } & \text { mògo } & \text { kàranden } & \text { sòto } & \text { kóòben } \\ \text { 2PL } & \text { POT man } & \text { learned } & \text { obtain } & \text { many }\end{array}$




\begin{tabular}{|c|c|c|}
\hline náá & mògó & kàràndén \\
\hline náa & mòg & kàranden \\
\hline 2PL PFV.NEG & man & learned \\
\hline
\end{tabular}

'Did you have a lot of educated people [in your village] or didn't you have any educated people?'

(KKEC_AV_CONV_131220_mosque4_SP2_09)

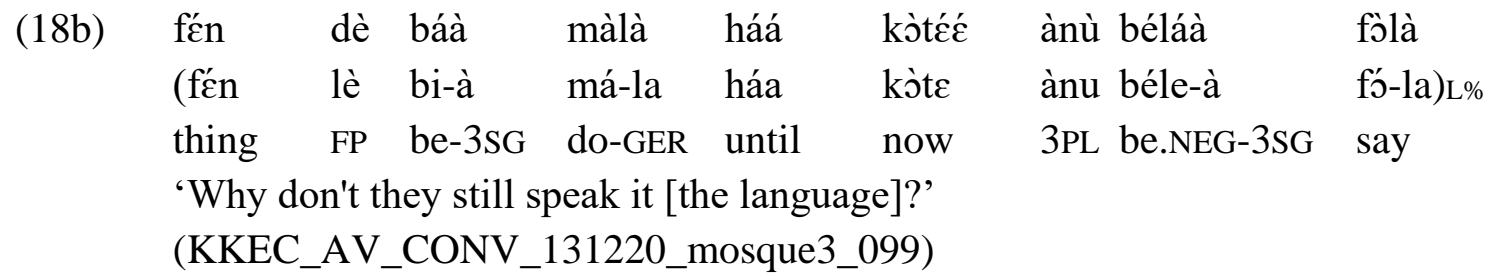

The High boundary tone $-\mathrm{H} \%$, realized as a High tone on the last syllable of the Intonation Phrase - is triggered by negation in main clauses. ${ }^{8}$ It can only appear in contexts where there is no $\mathrm{L} \%$, i.e. $\mathrm{H} \%$ is restricted to non-interrogative negative main clauses. For example, in (19), the clause is syntactically independent, non-interrogative, and contains negation, hence it ends in an $\mathrm{H} \%$.

$$
\begin{array}{lllll}
\text { háráy } & \text { má máá } & \text { súúmáyè } & \text { tòtì } \uparrow a ́ \\
\text { (háray } & \text { mà } & \text { máa } & \text { súumaye-È } & \text { totína) }{ }_{H} \% \\
\text { DISC } & 1 P L & \text { PFV.NEG } & \text { fest-ART } & \text { spoil }
\end{array}
$$

'We do not fail to fast.'

Subordinate clauses do not form their own Intonation Phrase, hence in constructions with subordination, boundary tones triggered by the main clause appear after the subordinate clause. For example, in (20a) the conditional clause sààn máá gbéć túgún 'if it is not clean' belongs to the same Intonation Phrase as the following main clause. It does not carry its own boundary tone (even though it contains negation), but the entire sentence ends in an L\%, triggered by the affirmative main clause. By the same logic, the L\% also appears at the end of the sentence when the order of the main and subordinate clauses is reversed (20b).

$\begin{array}{lllllllll}\text { (20a) sáánù } & \text { máá } & \text { gbéć } & \text { túgún } & \text { ì } & \text { náànù tónààtì } & \text { tùgùn } \\ & \text { (sì-ànu } & \text { máa } & \text { gbéc } & \text { túgun } & \text { ì } & \text { ni-ànu } & \text { tonàati } & \text { túgun)L\% } \\ \text { if-3PL } & \text { ID.NEG } & \text { be.clean again } & \text { 2SG OPT 3PL } & \text { REP-carry } & \text { again }\end{array}$

[When you go to the market with the corn] 'If it is not clean, you have to carry it back home.'

(KKEC_AV_CONV_131220_mosque1_155)

\footnotetext{
${ }^{8}$ Kakabe also has a continuation $\mathrm{H} \%$ boundary tone that is used by the speakers to signal that an utterance is incomplete and could or will be continued. So far, the relationship between the negation $\mathrm{H} \%$ and the continuation $\mathrm{H} \%$ remains unclear; we consider them to be two distinct boundary tones. For a detailed discussion of boundary tones, see Vydrina (2017: 527-554).
} 
'This one is my apprentice if that one is not present.'

(KKEC_AV_CONV_131220_carpentry_072)

Crucially, since negation triggers an $\mathrm{H} \%$ tone at the end of the Intonation Phrase - but only in main non-interrogative clauses - it can be used in Kakabe as an additional test for distinguishing between independent and subordinate clauses. ${ }^{9}$ For example, the $\mathrm{H} \%$ negation tone is not licensed by relative, conditional or temporal clauses: all these types of subordinate clause belong to the same Intonation Phrase as the main clause and do not bear their own boundary tone.

If reported speech functioned as a subordinate clause - as it does in constructions with "canonical" indirect speech in English - one would expect it to end in a boundary tone triggered by the main clause, cf. L\% in (20b). This would be independent of whether or not it contains negation, i.e. one would expect negation not to trigger an $\mathrm{H} \%$ boundary tone on subordinate speech reports. Yet that prediction turns out to be false. When a speech report contains negation, it ends with an H\%, as in (21), see Figure 6.

$\begin{array}{rlllll}\text { (21) mà kó } & \text { vìzítว̀ } & \text { nón } & \text { à bélé } & \text { sààràlá } \\ \text { mà } & \text { kó } & \text { (vìzítə-E } & \text { nón } & \text { à béle } & \text { sàara-la)H\% } \\ \text { 1PL } & \text { say } & \text { visit-ART } & \text { DISC } & \text { 3SG be.NEG } & \text { pay-GER }\end{array}$

'We said: The consultations are free of charge.' (Lit. "The visit is not paid for").

(KKEC_AV_NARR_150124_AK2_125)

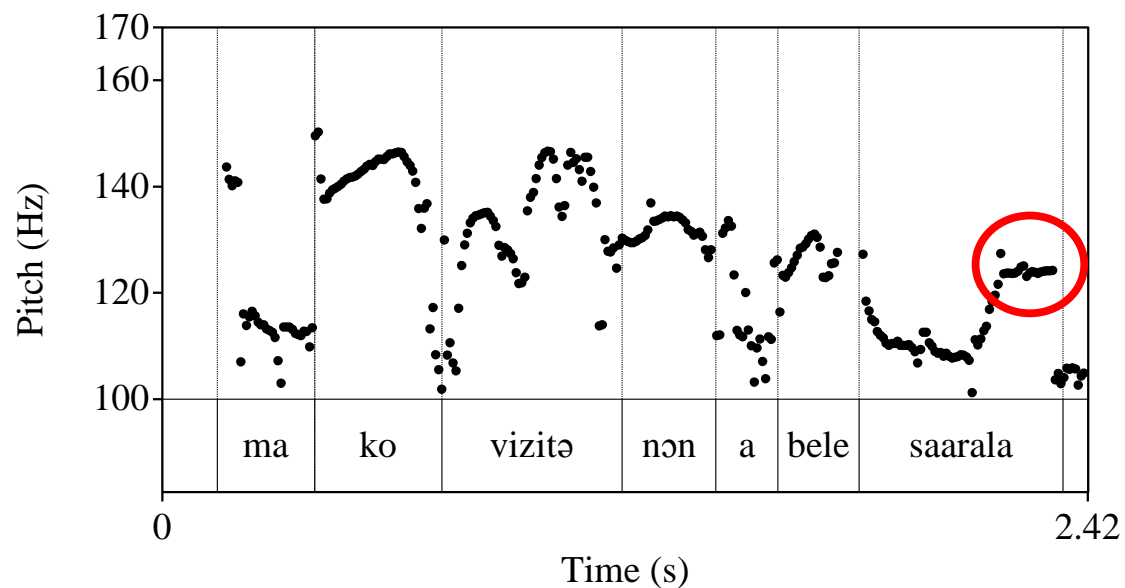

Figure 6. Pitch curve illustrating the appearance of an $\mathrm{H} \%$ triggered by negation at the end of a speech report

\footnotetext{
${ }^{9}$ Another important test for subordination - focus raising - is discussed in the next section. In practice, subordinate clauses are easily distinguishable from main clauses as they normally feature some kind of special marking, such as a relativizer or a special set of subordinate TAM markers. It is unclear, however, whether this criterion should also be applied to constructions with reported speech (even though it would give results consistent with our line of argument).
} 
The presence of a negation $\mathrm{H} \%$ tone at the end of a speech report with the negation strongly suggests that the report is syntactically independent. The construction with a speech report does not involve subordination but consists of two autonomous parts, as is typical crosslinguistically of constructions with direct speech.

\subsection{Absence of focus raising}

Kakabe disallows the expression of focus in subordinate clauses. This is in line with a more general cross-linguistic tendency: restrictions on the expression of information structure categories within subordinate clauses have been reported for a number of unrelated languages, including Tundra Yukagir (Matic 2014), Aghem (Hyman and Polinsky 2009), and Somali (Saeed 2004: 269-270). In languages where overt marking of information structure categories such as topic and focus is not allowed inside a dependent clause, the corresponding meanings are either left unspecified or expressed indirectly (Matić et al. 2014: 14). In Kakabe, focalization in subordinate clauses is expressed through what can be described as focus raising, i.e. the focus marker appears in the main clause.

In main clauses, focalization is expressed by the focus particle le cliticized to the constituent in focus, cf. (22a) and (22b).

$\begin{array}{lllll}\text { mùséé } & \text { lè } & \text { ká } & \text { sòbéé } & \text { tàbì } \\ \text { mùsu-È } & \text { lè } & \text { ka } & \text { sòbo-È } & \text { tàbi } \\ \text { woman-ART } & \text { FP } & \text { PFV.TR } & \text { meat-ART } & \text { prepare } \\ \text { 'THE WOMAN } & \text { prepared the } & \text { meat.' } & \text { (elicited) }\end{array}$

$(22 b)$

$\begin{array}{llll}\text { mùséè } & \text { ká } & \text { sòbéé } & \text { lé tàbì } \\ \text { mùsu-È } & \text { ka } & \text { sòbo-È } & \text { lè tàbi } \\ \text { woman-ART } & \text { PFV.TR } & \text { meat-ART } & \text { FP prepare } \\ \text { 'The woman prepared } & \text { THE MEAT.' } & \text { (elicited) }\end{array}$

Strikingly, when the focalized constituent is part of a subordinate clause, the focus marker appears in the main clause. In (23), the object in the purpose clause is in focus, and lè appears in the main, rather than in the subordinate clause. In (24), the entire subordinate clause is in focus, and the particle lè appears again in the main clause.

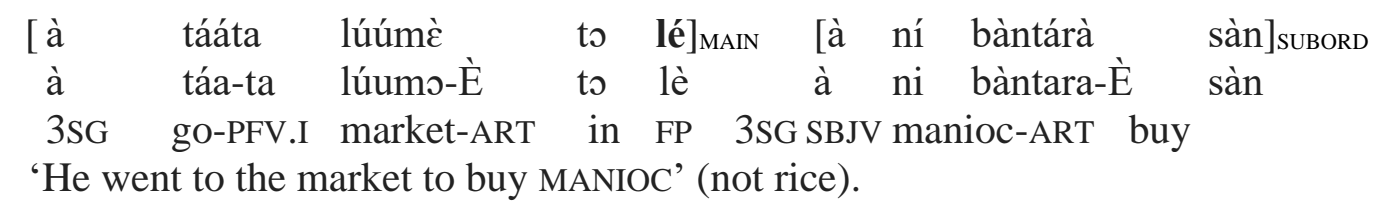




$\begin{array}{cllllll}\text { [ káá } & \text { wò bì } & \text { táálá } & \text { lè] }]_{\text {MAIN }} & \text { [wò nì } & \text { wó dòn] }]_{\text {SUBORD }} \\ \text { káa } & \text { wò bi } & \text { táa-la } & \text { lè } & \text { wò ni } & \text { wò dòn } \\ \text { or.Q } & \text { 2PL be } & \text { go-GER } & \text { FP } & \text { 2PL SBJV } & \text { 2PL dance }\end{array}$

'[Do you go there TO STUDY] or do you go there IN ORDER TO DANCE?'

(KKEC_AV_CONV_131207_talk04_033)

Unlike constructions with subordinate clauses, constructions with reported speech do not impose any restrictions on the expression of focus in situ. In (25) the focus is on the subject of the speech report, and the focus particle appears inside the speech report, right after the focused subject. In (25), the focus particle again appears next to the focused constituent with a speech report, this time it is an object.

\begin{tabular}{|c|c|c|c|}
\hline báà & nón & mòว̀nì & sóngè \\
\hline bi-à & fó-la & mòoni & sóngo-È \\
\hline SG be-3SG & say-GER DISC & porridge & price-ART \\
\hline lè & yáà & dílá & mùséè \\
\hline lyi-È lè & bi-à & dí-la & mùsu-È \\
\hline RT FP & be-3sG & give-GER & woman-ART \\
\hline
\end{tabular}

'I was saying: [As for] the money for the porridge, it is THE MAN who is giving it to the woman.'

(KKEC_AV_CONV_131207_TALK03_053)

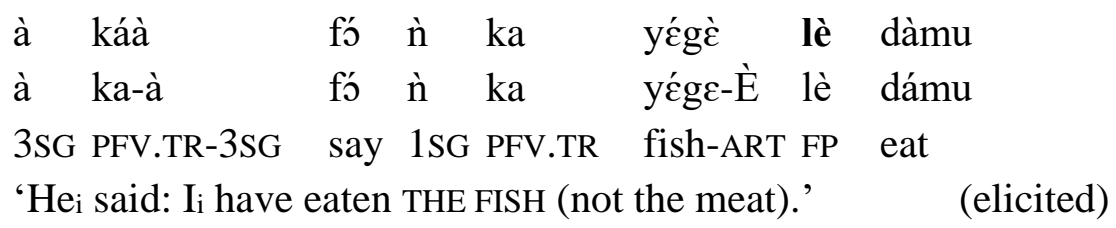

We take the absence of focus raising in examples such as (25)-(26) as evidence for the syntactic autonomy of the two parts of the speech reporting construction; this is consistent with the prosodic evidence discussed above.

One type of speech report - reported commands - seems to differ from the rest in patterning with subordinate clauses. On closer inspection, however, this behavior is predicted by the special properties of expressions of command.

There are two ways to report a command in Kakabe. First, commands can be reported using a subordinate clause in the subjunctive. As predicted for all subordinate clauses, focus is raised from the subjunctive clause (27). This expression of command is, in this sense, no exception to the general rule of focus raising.

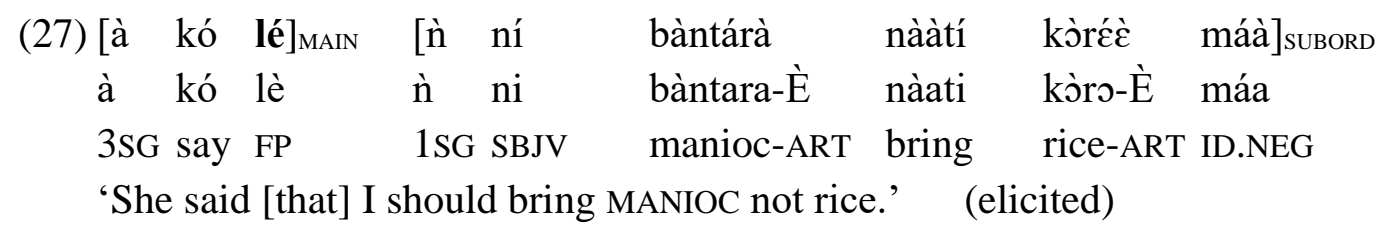


Second, commands can be reported in the imperative, just as they were - or could be originally uttered. Imperative clauses, however, are structurally reduced in Kakabe and do not share the full inventory of properties with finite clauses. In particular, they do not allow for the expression of focus, presumably due to their deficient structure. As shown in (28), the focus marker cannot be used within an imperative clause: ${ }^{10}$

$$
\begin{aligned}
& \text { y'́gè } \quad(* l e ̀) \quad \text { sàn } \\
& \text { yége-È lè sàn } \\
& \text { fish-ART (FP) buy } \\
& \text { 'Buy some fish (not meat).' (elicited) }
\end{aligned}
$$

Consistent with this property, when an imperative clause represents reported speech, its constituents can be focused through focus raising: the focus marker can appear in the main clause, even though it is associated with a constituent within the speech report. In (29a), the focused constituent is the object within a speech report, yet the focus marker appears at the

\begin{tabular}{|c|c|c|c|c|c|}
\hline à & kó lè & 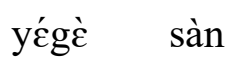 & sòbéè & máá & dè \\
\hline à & kó lè & y'́ge-̇̀ sàn & sòbo-È & máa & dè \\
\hline $3 \mathrm{SG}$ & ay FP & fish-ART buy & meat-ART & ID.NEG & EMPH \\
\hline
\end{tabular}
end of the speech-introducing part of the construction, after the quotative marker kó:

$\begin{array}{lllllll}\text { *à } & \text { kó } & \text { y'́gè } & \text { lè } & \text { sàn sòbéè } & \text { máá } & \text { dè } \\ \text { à } & \text { kó } & \text { y'́ge-È } & \text { lè } & \text { sàn sòbo-È } & \text { máa } & \text { dè } \\ 3 \text { 3SG say } & \text { fish-ART } & \text { FP } & \text { buy meat-ART } & \text { ID.NEG } & \text { EMPH }\end{array}$

We conclude that focus raising in Kakabe is obligatory in constructions with subordination but only occurs in constructions with reported speech when the speech report is for some reasons prevented from hosting the focus marker. This suggests that constructions with reported speech do not involve syntactic subordination but are characterized instead by a relatively high degree of syntactic autonomy of the construction's parts.

\subsection{Summary}

In this section we have shown that the two parts of the speech reporting construction in Kakabe are rather loosely related and that the relationship does not involve syntactic subordination. The relative autonomy of the two parts is suggested by a number of phenomena.

With respect to licensing, reported speech need not be introduced by any specific verb of speaking, and it also need not be licensed by a quotative marker or any other predicate.

\footnotetext{
10 As suggested by a reviewer, this property could be alternatively explained by the imperatives' being "inherently focused" (Hyman \& Watters 1984). We believe, however, that this explanation alone would not account well for the fact that constituents of an imperative clause can be focused through focus raising, i.e. there is no prohibition against expressing focus with imperatives, as long as the focus is expressed outside the clause.
} 
Reported speech can stand on its own, and can then only be interpreted as such based on contextual cues such as the question-answer structure of a dialogue or an expressive opening with an interjection or an address term. The optionality of the speech-introducing part of the construction is a prominent cross-linguistic property of reported speech (cf. Spronck \& Nikitina 2019). While characteristic of loosely related structures of the direct speech type, it is normally not attested with subordinate clauses. This suggests that in the case of Kakabe, we are dealing with an apparently universal paratactic structure that is similar to the structure of direct speech reports in European languages.

With respect to its syntax, reported speech in Kakabe also does not behave as a subordinate clause, with the exception of reported commands. Unlike subordinate clauses, it can accommodate a broad range of extra-clausal elements, including extraposed noun phrases, address terms, and interjections. Prosodically, reported speech differs from subordinate clauses in not having to be integrated into the same Intonation Phrase as the construction's speech-introducing part. The prosodic autonomy of reported speech is reflected in the use of its own boundary tone. An additional piece of evidence for the non-subordinate status of reported speech comes from a typologically rare phenomenon attested in Kakabe: focus raising. While subordinate clauses cannot accommodate their own focus marker and pass it on to the main clause, the focus marker can appear within reported speech. The only exception to this generalization are reported commands, which, we argued, are either expressed in Kakabe through subordinate clauses in the subjunctive or through not being able to host their own focus markers for syntactic reasons independent of their reported status (in the case of imperatives).

We conclude that with the exception of reported commands in the subjunctive, Kakabe reported speech constructions do not involve syntactic subordination. They instantiate instead the seemingly universal apposition-like structure consisting of two parts: an optional speechevent introducing part, and reported speech. We now proceed to discuss the way pronouns are used in reported speech, and to argue that the reported indexicality in Kakabe is flexible while the choice of pronominals is independent of the construction's syntax.

\section{Pronominal indexicality in reported speech}

\subsection{Flexible interpretation}

Some of the speech reports in our corpus involve indexical shifts, others do not. As we show later on, both shifted and non-shifted interpretations are attested in the same construction type - the basic speech reporting construction discussed in the previous section.

The second person pronoun $i$ in the speech report in (30) is interpreted in the context of the reported speech situation, as in direct speech. Yet in the response to that utterance, reported in the following sentence, the reported speaker is referred to by a third person pronoun, as in European indirect speech.
(30) ̀̀ kó tága jó̀̀
la wò-nu si-ì
madècman
kó à béle
tága-la
1SG say go there
OBL that-PL POT-2SG help
QU 3SG be.NEG
go-GER
'I said: Go there, they will help you. - [Shei said]: Shei will not go.' 
(KKE-C_2013-12-27_AK-NARR-3-155)

The excerpt in (31) is from a tale about a boy who stole meat from his friend. In this excerpt the boy is summoned to the chief to be judged and is asking for forgiveness. The example is noteworthy for our discussion in several respects. First, it illustrates alternating pronominal deixis: direct indexicality in (a)-(c) is followed by indirect-like pronominal use in (d)-(e). Note that the transition between the two pronominal strategies corresponding to the boundary between (c) and (d) is demarcated just by a single instance of the quotative marker kó. Second, (d) where the third person pronoun $\dot{a}$ is interpreted in the context of the current speech situation, contains the temporal adverb bii 'today' that seems to be interpreted in the context of the reported speech situation. ${ }^{11}$ The same clause (d) contains the interjection yándi 'please', which is also interpreted in the context of the reported speech situation (see Section 4.2. for more examples with interjections). ${ }^{12}$

(31) Excerpt from a tale about a boy thief:

$\begin{array}{llllll}\text { a. dénnéc̀ } & \text { nàtà } & \text { à } & \text { kó } & \text { mànsáà } & \text { mà } \\ \text { dénden-È } & \text { nà-ta } & \text { à } & \text { kó } & \text { mànsa-È } & \text { ma } \\ \text { boy-ART } & \text { come-PFV.I } & \text { 3SG say chief-ART } & \text { to }\end{array}$

'The boy came and said to the chief:

(introduction to speech report)

$\begin{array}{llllll}\text { b. kó } & \text { bá } & { }^{\dagger} \text { ń mààmà } & \text { nááfyònè } & \text { lè } \\ \text { kó } & \text { báyî } & \text { ǹ } & \text { màama } & \text { náafyon-È } & \text { lè } \\ \text { QU } & \text { because } & \text { 1SG grandmother blind-ART } & \text { ID }\end{array}$
since my grandmother is blind,

$\left(1^{\text {st }}\right.$ person $=$ reported speaker $)$

\footnotetext{
${ }^{11}$ Interpretation of the evidence of temporal adverbs, however, depends on whether Kakabe has truly deictic adverbs or whether the deictic interpretation arises in context due to the general salience of the moment of speaking as a temporal reference point. We believe that adverbs such as 'yesterday' or 'today' are in fact nondeictic in Kakabe, and should be translated as 'the day before' and 'that day', cf. the following examples where they are interpreted with respect to a contextually salient point in the past:
(ii) mò táá tàfólóbì̀ táláátá túgún
mò báti-à tafólıbìi tálaata túgun

1PL PFV.OF-3SG start today Tuesday again

'[Yesterday, we worked until night]. We have started again today - on Tuesday.'

(SAJOYA_SNKEITA_2009_022)

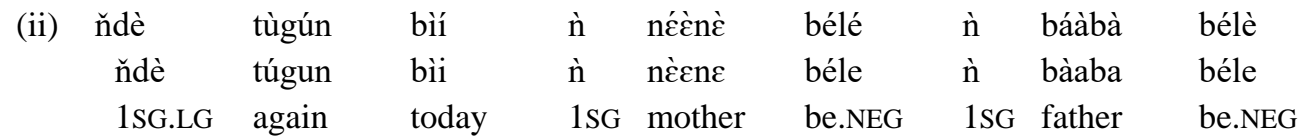

'At that time, I did not have my mother or my father [with me].'

(KKEC_AV_NARR_131227_AK3_043)

${ }^{12}$ A reviewer suggests that in this example, the boy could be addressing the chief through an intermediary, which could motivate the third-person reference to the chief. This interpretation, however, would leave unexplained the use of third person to refer to the speaker in (d) and (e).
} 
c. kúlànù bí mà lá sènéc̀ tò

kùla-È-nu bí mà la sène-È to

monkey-ART-PL be 1PL POSS field-ART in

and there are monkeys in our field, $\quad\left(1^{\text {st }}\right.$ person $=$ reported speaker $)$

d. kó bìi à ní yààfáà mà yándi

kó bìi à ni yàafe-à ma yándi

QU today 3SG SBJV forgive-3SG to please!

he (= the chief) should forgive him (=the boy), please,

$\left(3^{\text {rd }}\right.$ person $=$ reported speaker $\& 3^{\text {rd }}$ person $=$ reported listener $)$

e. à náà wà kà kùláànù kàntàn

à ni-à wá kà kùla-È-nu kántan

3SG SBJV-3SG go INF monkey-ART-PL keep

he (=the chief) should let him (= the boy) go to guard [the field from] the monkeys.'

$\left(3^{\text {rd }}\right.$ person $=$ reported speaker $\& 3^{\text {rd }}$ person $=$ reported listener $)$

(KANKAYA_AB_2008_075)

\subsection{Preferences in pronominal use}

One of the factors in the choice of a pronominal strategy in our data is genre. Table 1 shows the distribution of the direct and indirect strategies across different text types, in a selection of examples where reported speech is introduced by kó, either in the function of a defective speech verb or in the function of a quotative marker. On the direct strategy first and second person pronouns are used to refer to the reported speaker and addressee; third person is used to refer to the current speaker. On the indirect strategy first and second person pronouns are reserved for the current speaker and addressee; third person is used to refer to the reported speaker and addressee. A number of instances of reported speech cannot be classified as direct or indirect because they do not involve first or second person pronouns and do not refer to the current or the reported speaker and addressee. While the overall proportion of direct and indirect speech reports in our data is roughly the same, their distribution in specific genres is skewed. Indirect speech reports predominate in conversations and personal narratives, while direct reports are the dominant strategy in historical narratives and tales. The mixing of different strategies within the same clause is virtually unattested (with the exceptional cases of indexicality mismatches involving the use of address terms, as in (35).

Table 1: Pronominal indexicality and text types

\begin{tabular}{|l|l|l|l|l|l|ll|}
\hline & \multicolumn{2}{l}{ Direct } & \multicolumn{2}{l|}{ Indirect } & Under-specified & \multicolumn{2}{l|}{ Total } \\
\hline Conversation & 10 & $6,67 \%$ & $\mathbf{4 0}$ & $\mathbf{2 6 , 6 7 \%}$ & 100 & 150 & $(100 \%)$ \\
\hline Personal narrative & 99 & $25,45 \%$ & $\mathbf{1 3 3}$ & $\mathbf{3 4 , 1 9 \%}$ & 157 & 389 & $(100 \%)$ \\
\hline Historical narrative & $\mathbf{2 1}$ & $\mathbf{6 3 , 6 3 \%}$ & 3 & $9,09 \%$ & 9 & 33 & $(100 \%)$ \\
\hline Tale & $\mathbf{6 2}$ & $\mathbf{5 9 , 0 5 \%}$ & 18 & $17,14 \%$ & 25 & 105 & $(100 \%)$ \\
\hline Total & 190 & $27,98 \%$ & 192 & $28,13 \%$ & 295 & 679 & $(100 \%)$ \\
\hline
\end{tabular}


We believe that the different tendencies in the use of the direct and the indirect pronominal strategies correlate with different degrees of involvement of the participants of the current speech situation in the reported speech situation. In conversations, the related events can potentially involve both the current speaker and the current addressee. In personal narratives, the reported speech situation often involves the current speaker but not the current addressee. In historical narratives and tales, on the other hand, the current speaker and addressee are in general not expected to be involved in any way in the reported events.

This distribution suggests that the choice of pronominal strategy is sensitive to the need to avoid potential confusion between the current speaker/listener and the story's characters. The same need has been argued by Nikitina (2012a, 2018) to affect, in some logophoric languages, the choice between logophoric and first person pronouns. The indirect pronominal strategy of Kakabe is in this sense parallel to the logophoric strategy of some other languages in allowing the storytellers to distinguish, in reported speech, their own persona from that of their characters.

The excerpt from a personal narrative in $(32 \mathrm{a}-\mathrm{c})$ illustrates the use of the indirect pronominal strategy to this effect. It comes from a story about a trip the speaker took to work. The segments (a) and (b) report speech addressed to the narrator by his boss. The reported speech situation involves the current speaker (as the addressee), making the roles of the current speaker and the narrator as a participant in the past event dangerously close. Consistent with the general tendency, the first person pronoun is reserved here for the current speaker and therefore does not refer to the boss. The excerpt is consistent in associating the first person with the current speaker, yet it looks inconsistent from the point of view of the commonly assumed direct and indirect prototypes: from the European perspective, the use of the first person in (a)-(b) would qualify as an instance of indirect, and its use in (c), as one of direct speech.

(32) Excerpt from a personal narrative

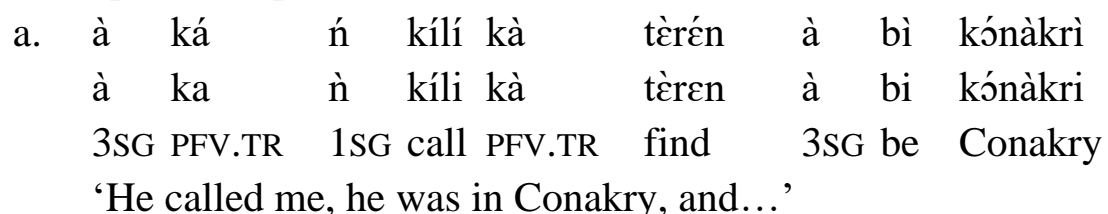

$\begin{array}{llllllll}\text { b. } & \text { kó } & \text { kònò à báà } & \text { fólá } & \text { ̀̀ } & \text { dórón } & \text { dè } & \text { yèn } \\ \text { kó } & \text { kòno à } & \text { bi-à } & \text { fó-la } & \text { ǹ } & \text { dóron } & \text { lè } & \text { yen } \\ \text { QU } & \text { but 3SG be-3SG } & \text { say-GER } & \text { 1SG only } & \text { FP } & \text { BNF }\end{array}$

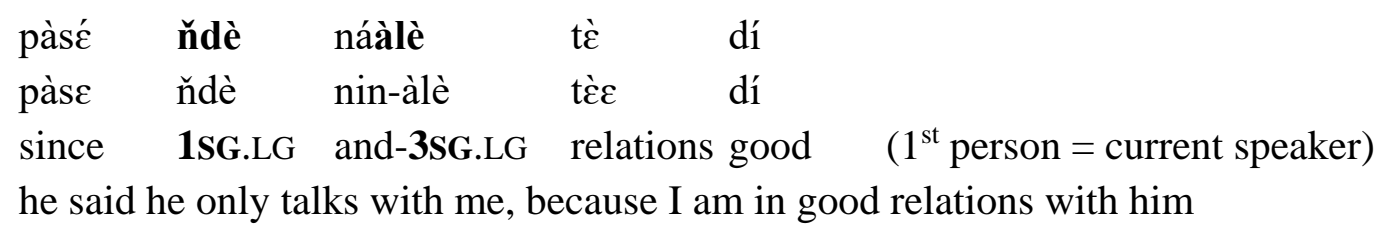

\begin{tabular}{llllllll} 
c. & ǹ kó àwà & ǹ & kó & i & mání & pèré \\
ǹ kó àwa & ǹ & kó & ì & máni & père \\
1SG say okay & \multicolumn{1}{c}{ 1SG say } & 2SG COND & be.ready
\end{tabular} 
ì sí ń tèrèn ǹ bí yàn

ì si ̀̀ tèren ̀̀ bi yàn

2SG POT 1SG find 1SG be here

$\left(1^{\text {st }}\right.$ person $=$ current speaker $)$

I said: Okay, when you are ready, you will find me there.'

(KKEC_AV_CONV_150124_AK2)

Genre, or rather, the degree of involvement of the current speaker in the events she or he is narrating, is but one of the factors that influences the choice of pronominal strategy. Among other factors that seem to play a role in our corpus is the level of individuation or salience of the reported speaker: the indirect strategy is more likely to be used in reports of speech uttered by a group of weakly individuated characters or by a non-salient or episodic character than in reports of the primary character's speech. Position within the narrative - in the scene-setting portion, at the culmination, at the end of the narrative - also seems to play a role. Since we focus here on the (absence of) interaction between the choice of a pronominal strategy and the syntax of reported speech, we leave the detailed treatment of these factors for a separate study. What is important for us is the fact that pronominal indexicality is variable within Kakabe discourse reports, but as we show in the next section, that variability cannot be related to a difference in the syntactic type of the speech report.

\section{Pronominal indexicality is independent of syntax}

\subsection{How reported speech is introduced}

The examples in Section 2 involved direct pronominal deixis. We will now show that the same properties characterize speech reports with the indirect strategy, i.e. that the choice of pronouns cannot be reliably related to the construction's syntax. In what follows we demonstrate that indirect pronominal deixis is attested in combination with syntactic features that point to a non-subordinate status of the speech report.

Speech reports with indirect pronominal deixis are introduced in exactly the same ways as speech reports with direct deixis. In (33), for example, the report is introduced by the defective speech verb kó in combination with a (homophonous) quotative marker.

$\begin{array}{lllll}\text { à } & \text { dìnnógè } & \text { kò } & \text { tùgùn } & \text { kó } \\ \text { à } & \text { dìnnógo-È } & \text { kó } & \text { túgun } & \text { kó } \\ \text { 3SG friend-ART } & \text { say } & \text { again } & \text { QU }\end{array}$

$\begin{array}{llll}\text { ń ní } & \text { wáá } & \text { bíníwórówilà }{ }^{\star} \text { dáà } & \text { bòlò } \\ \text { ǹ ni } & \text { wáa } & \text { bí íwórówila dí-à } & \text { bólo } \\ \text { 1SG SBJV } & \text { thousand } & \text { seventy give-3SG } & \text { hand }\end{array}$

'His friendi also said [that] I should give himi seventy thousand.'

(KKEC_AV_CONV_150124_AK2_163) 
Speech reports with indirect deixis need not be introduced by anything at all. In (34) the reported speech is not introduced by any element normally associated with speech reports. The characters referred to in the third person plural are trying to talk a girl into helping them, promising to give her a cow and then asking if there is any delicacy she would like to have (with the intention of offering it to her). The reported speech interpretation of the question is reinforced by a dialogic structure: the question is followed by the girl's negative answer.

$$
\begin{aligned}
& \text { àn ká kè mádìá kàà kó nìngéè } \\
& \text { ànu ka kè madìya kà-à kó nìngi-È } \\
& \text { 3PL PFV.TR that pray INF-3SG give cow-ART } \\
& \text { [à bélé wó tábírí númá kélá à náà dàmù]? } \\
& \text { à béle wó tábiri nùma ké-la à ni-à dámu } \\
& \text { 3SG be.NEG POL food good do-GER 3SG SBJV-3SG eat }
\end{aligned}
$$

(KKE-C_2013-12-20_KP_TALE-3-076)

The examples illustrate the absence of any systematic difference in the licensing properties between speech reporting constructions with the two types of pronominal strategy. Crucially, the indirect strategy is attested in speech reports that are more naturally analyzed as independent clauses - speech reports that appear without an overt licensor and are only interpreted as such based on context and sometimes intonational cues.

\subsection{Interjections and address terms}

Like speech reports with direct pronominal deixis, reports with indirect pronouns accommodate all sorts of extra-sentential elements, including interjections and address terms. In (35), the speech report features the address ì dinnjog̀ 'my friend', even though the reported addressee is encoded by a third person pronoun:

$\begin{array}{clllllllll}\text { (35) ǹ wúlítá } & \text { ǹ } & \text { kó } & \text { ǹ } & \text { dínnógè } & \text { à } & \text { ní } & \text { ń } & \text { málò } \\ \text { ǹ } & \text { wúli-ta } & \text { ǹ } & \text { kó } & \grave{n} & \text { dínnògo-È } & \text { à } & \text { ni } & \text { ǹ } & \text { malò } \\ \text { 1SG stand.up-PFV.I } & \text { 1SG } & \text { say } & \text { 1SG friend-ART } & \text { 3SG } & \text { SBJV } & \text { 1SG accompany }\end{array}$

'I stood up and said: My friend, you should come with me.'

(KKEC_AV_NARR_131227_AK2_037)

The reported speech in (36) also contains the address ànsúmànù (personal name); the first and third person pronouns within the report, however, are indirect, i.e. interpreted in the context of the current speech situation. ${ }^{13}$

\footnotetext{
${ }^{13}$ As already mentioned, extra-sentential elements are commonly introduced in Kakabe by a separate quotative marker, attesting to their loose integration in the sentence structure.
} 


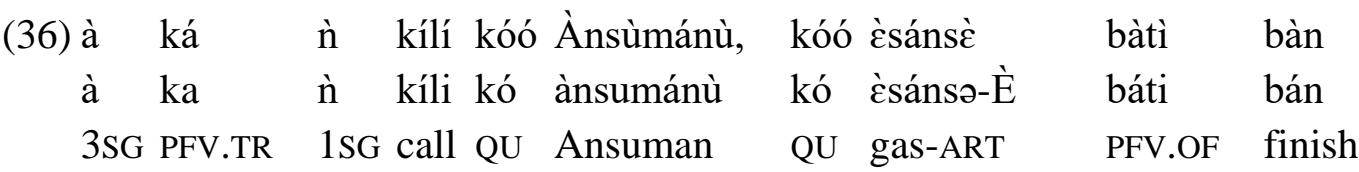

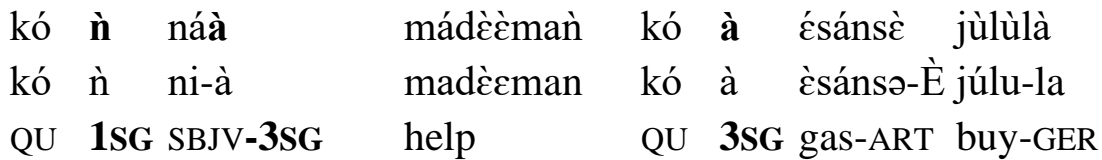

'She called me and said: Ansuman, the gas is out. I should help him buy gas.'

(KKEC_AV_CONV_150124_AK2_159)

In (37) the report is opened by an interjection, but the reported addressee is referred to using a third person pronoun:

$\begin{array}{llllll}\text { ǹ kó àwà } & \text { à ní } & \text { lítírí náání } & \text { jùlù } \\ \text { ǹ kó àwa } & \text { à ni } & \text { lítri náanì } & \text { júlu } \\ \text { 1SG say well } & \text { 3SG SBJV } & \text { litre four } & \text { buy } \\ \text { 'I said: Okay, he should buy four liters.' }\end{array}$

(KKEC_AV_CONV_150124_AK2_159)

In sum, both direct and indirect pronominal deixis are compatible with extra-sentential elements, suggesting that neither is associated with subordinate syntax. Crucially, the indirect pronominal strategy is well attested in combination with interjections and address terms, suggesting again that it is not restricted to syntactically subordinate clauses.

\subsection{Absence of prosodic integration}

Reports with indirect deixis need not be integrated prosodically into the speech-event introducing part of the construction. First, unlike subordinate clauses, they are not subject to obligatory downdrift. In (38) the first person pronoun is interpreted in the context of the current speech situation ("our place" refers to the place associated with the story's narrator). The $\mathrm{H}$ tone on the pronoun shows no evidence of a downdrift, suggesting that the speech report is not a subordinate clause (Figure 7): 
àn kó `ándè bélé wó fèć má `bátá yàn

ànu kó ànú-lè béle wò $f \varepsilon$ mà bàta yàn

3PL say 3PL-LG be.NEG that with 1PL at here

'Theyi said: Theyi did not want it (= the institutions) here at our place.'

(KKEC_AV_CONV_131221_labiko1_240)

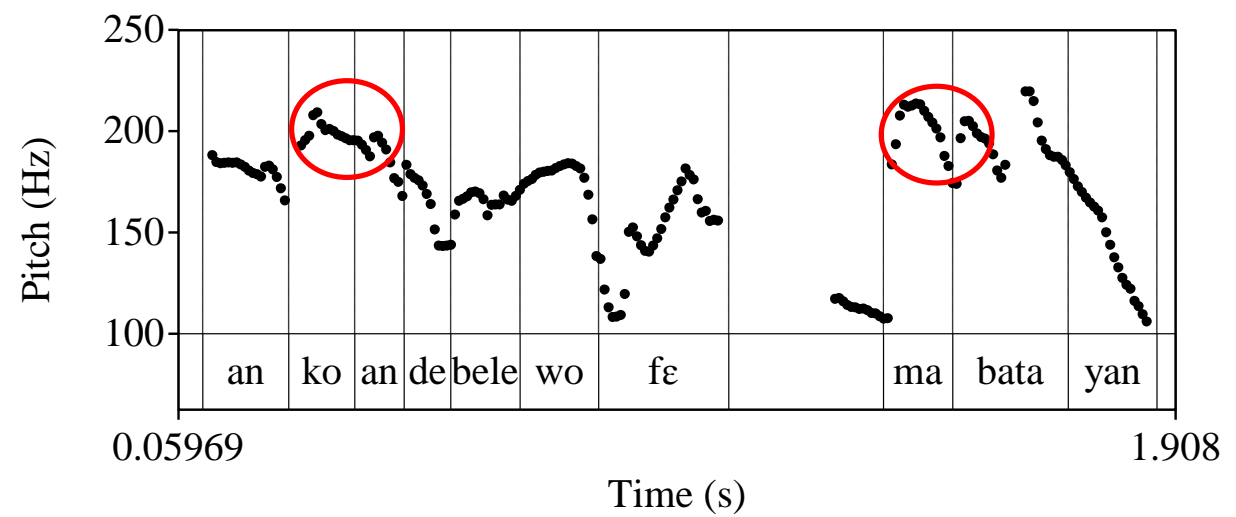

Figure 7. Pitch curve illustrating the absence of prosodic integration of a speech report with indirect pronouns (the absence of dowdrift)

In (39), too, the $\mathrm{H}$ tone on yàn' 'here' is at the same level as the $\mathrm{H}$ on the quotative marker kó, showing again that the speech report does not form an Intonation Phrase with the speechevent introducing part of the construction (Figure 8):

$\begin{array}{lllllll}\text { à } & \text { kó } & \text { à } & \text { káà } & \text { tó } & \text { yàń } & \text { dè } \\ \text { à } & \text { kó } & \text { à } & \text { ka-à } & \text { tó } & \text { yàn } & \text { lè } \\ \text { 3SG } & \text { say } & \text { 3SG } & \text { PFV.TR-3SG } & \text { leave } & \text { here } & \text { FP }\end{array}$

'He $\mathrm{H}_{\mathrm{i}}$ said [that] he $\mathrm{i}_{\mathrm{i}}$ was leaving it here.'

(KKEC_AV_CONV_131220_tale3_SP6_063)

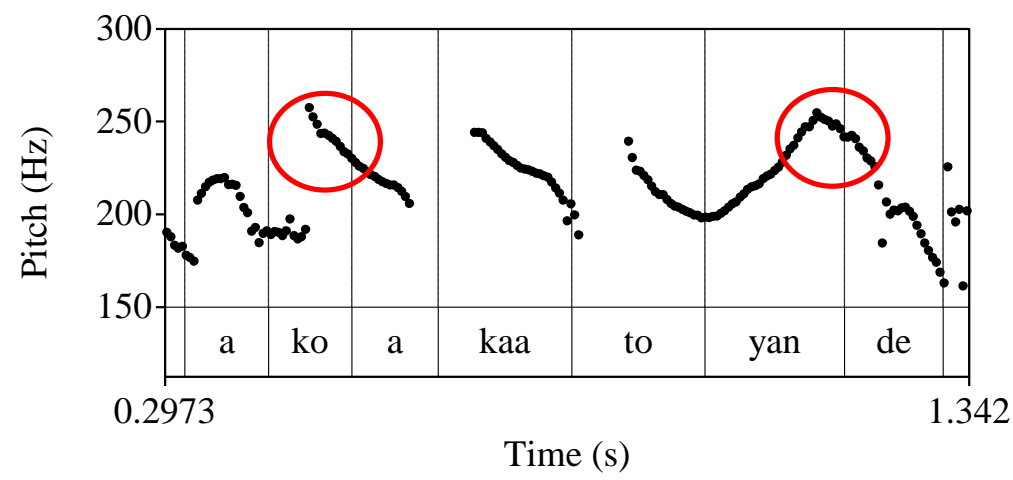

Figure 8. Pitch curve illustrating the absence of prosodic integration of a speech report with indirect pronouns (the absence of dowdrift)

Second, negation triggers an $\mathrm{H} \%$ boundary tone in speech reports with indirect pronouns, just as in speech reports with direct deixis (Figure 9): 

kó mà téé à lál’̀
kó (mà tée à lalò) ${ }_{H} \%$
QU 1PL POT.NEG 3SG build

'[They] said [that] we cannot build it.'

(KKEC_AV_CONV_131221_labiko1_155)

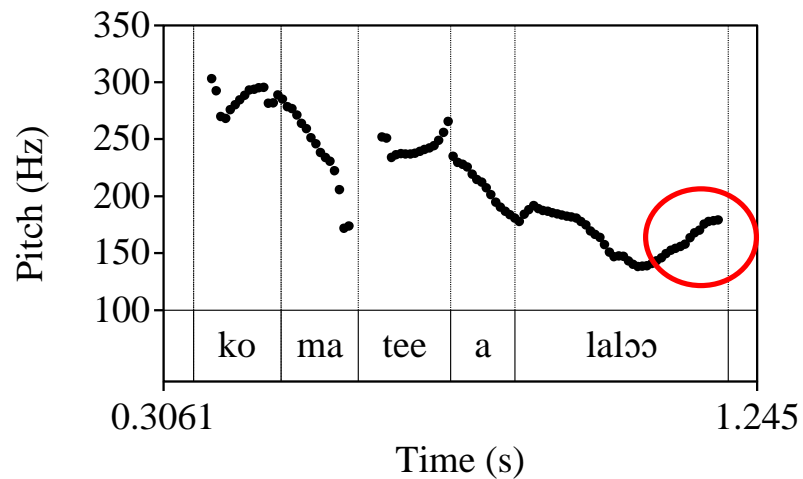

Figure 9. Pitch curve illustrating the presence of an $\mathrm{H} \%$ in a speech report with indirect pronouns

In sum, the two deictic strategies are associated with the same prosody, further confirming the view that the difference is not a matter of syntax. Crucially, the indirect pronominal strategy is attested in speech reports that behave as independent clauses according to prosodic criteria.

\subsection{Focus raising}

Finally, just like speech reports with direct discourse, reports with indirect deixis do not require focus raising. In (41), the focus marker appears within a speech report (see also 39). In a subordinate clause, it would instead appear in the main clause.
(41) à káà
fó à $\mathrm{ka}$
y'́gè lè dàmu
à ka-à
fó à ka
yége-È lè dámu
3SG PFV.TR-3SG
say 3SG PFV.TR fish-ART FP eat
'He $\mathrm{H}_{\mathrm{i}}$ said that he $\mathrm{i}_{\mathrm{i}}$ has eaten THE FISH (not the meat).'(elicited)

In sum, the two pronominal strategies share the same behavior with respect to focus raising, which distinguishes them both from subordinate clauses. Crucially, the indirect pronominal strategy is not restricted to constructions behaving as subordinate clauses based on the criterion of focus raising. 


\section{Discussion}

Speech reports with the two types of pronominal indexicality share all the relevant syntactic properties, suggesting that the pronominal interpretation is independent of syntax. The same construction type - the apposition-like structure with two loosely related parts - can be used with both direct and indirect pronominal deixis. Most importantly, the indirect pronominal strategy is well attested in constructions that show evidence of non-subordinate status, and the direct pronominal strategy is attested in reported commands with the subjunctive, which show evidence of subordination.

The choice between the two pronominal strategies seems to depend on a number of discourse properties that can probably be subsumed under the traditional notion of perspective, or viewpoint, or the degree of distancing (McGregor 1994; Evans 2013, inter alia). This could explain statistical tendencies in the association of direct pronominal strategies with certain other elements of the report which attest to the report's special semiotic status as a demonstration (Clark \& Gerrig 1990), such as interjections and exaggerated intonation patterns. Table 2 shows that interjections are more likely to co-occur with direct than indirect pronominal deixis ( $81 \%$ vs. $19 \%$ ), even though both combinations are quite well attested. ${ }^{14}$

Table 2: Pronominal deixis and interjections

\begin{tabular}{|l|c|c|l|}
\hline & $\begin{array}{c}\text { Direct pronominal } \\
\text { deixis }\end{array}$ & $\begin{array}{c}\text { Indirect pronominal } \\
\text { deixis }\end{array}$ & Total \\
\hline reports with interjections & $54 \mathbf{( 8 1 \% )}$ & $13(19 \%)$ & $67(100 \%)$ \\
\hline reports without interjections & $136(43 \%)$ & $179(\mathbf{5 7 \%})$ & $315(100 \%)$ \\
\hline
\end{tabular}

Symptomatically, the two strategies cannot be mixed within the same report, i.e. each report must be consistent in the choice of a deictic reference point, cf. consistent $(42 a, b)$ vs. mixed $(42 \mathrm{c}, \mathrm{d}) .{ }^{15}$

$\begin{array}{lllllll}\text { à } & \text { kó } & \text { kánkánè } & \text { mà } & \text { ǹ bátí̀ } & \text { yèn } \\ \text { à } & \text { kó } & \text { kánkan-È } & \text { ma } & \text { ǹ báti-ì } & \text { yèn } \\ \text { 3SG say } & \text { thief-ART } & \text { to } & \text { 1SG } & \text { PFV.OF-2SG } & \text { see }\end{array}$

'Hei told the thief: $\mathrm{I}_{\mathrm{i}}$ see you!' (elicited)

\begin{tabular}{|c|c|c|c|c|c|}
\hline à & kó kánkánè & mà & bátáà & yén & indirect deixis \\
\hline à & kó kánkan-È & $\mathrm{ma}$ & báti-à & yèn & \\
\hline $\mathrm{G}$ & say thief-ART & to & 3SG PFV.OF-3SG & see & \\
\hline
\end{tabular}

\footnotetext{
${ }^{14}$ Evidence for focus raising and boundary tones is only available in some of the examples in our database (since speech reports rarely have a focused constituent, and they do not always trigger a clearly visible boundary tone), preventing us from quantifying the distribution of pronominal strategies across syntactic construction types.

${ }^{15}$ This is in contrast to languages that allow or sometimes require the use of a mixed strategy, e.g. by conflating current and reported listeners but distinguishing between current and reported speakers (Nikitina 2012b).
} 


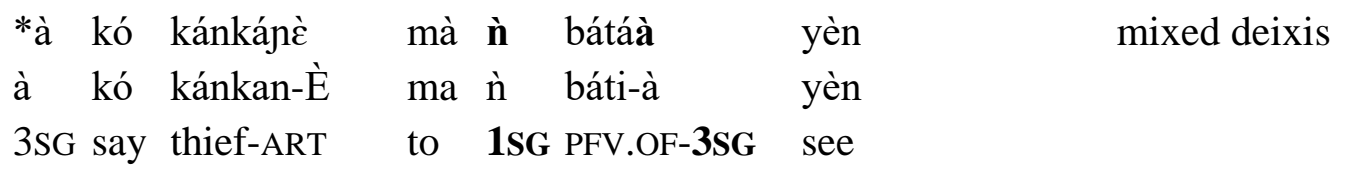

This consistency helps to explain an apparent puzzle in the choice of pronominal perspective in Kakabe. One type of speech report differs from others in only allowing one of the two pronominal strategies: reported commands encoded by imperatives can only include pronouns interpreted in the context of the reported speech situation, i.e. only direct pronouns. This restriction is illustrated in $(43 a, b)$ for objects and in $(44 a, b)$ for oblique arguments:

$\begin{array}{lll}\text { (43a) à } & \text { kó } & \text { ǹ déc̀màn } \\ \text { à } & \text { kó } & \text { ǹ dècman } \\ \text { 3SG } & \text { say } & \text { 1SG help }\end{array}$

'He said: Help me.' $\quad$ (elicited)

(43b) à kó à dèc̀màn

à kó à dècman

3SG say 3SG help

'Hei said: Help himj *i.' $^{\prime}$ (elicited)

(44a) à kó wótè dí ̀̀ bòlò

à kó wóti-È dí ̀̀ bólo

3SG say money-ART give 1SG hand

'He $\mathrm{i}_{\mathrm{i}}$ said: Give me the money.' (elicited)

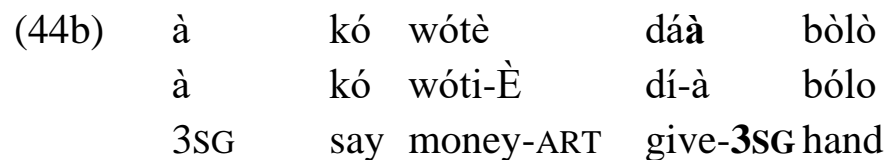

'He $\mathrm{i}_{\mathrm{i}}$ said: Give him $\mathrm{j}^{\prime} *_{\mathrm{i}}$ the money.' (elicited)

The restriction becomes less puzzling when one takes into account the fact that imperatives are associated with an unexpressed second person subject. If the unexpressed subject is assumed to be interpreted in the context of the reported speech situation, it follows naturally that the other pronouns in reported commands should receive a consistent interpretation, i.e. only direct deixis should be allowed. ${ }^{16}$

\footnotetext{
${ }^{16}$ The idea that imperatives are associated with unexpressed second person subjects is supported by the fact that in the imperative, objects of reflexive verbs are encoded by second person pronouns, just as in finite clauses with overt second person subjects, e.g. i kò 2SG wash 'wash yourself!'.
} 
Crucially, the choice of pronominal deixis cannot be predicted based on the construction's syntax, and the two types of deictic orientation are not systematically associated with two distinct constructional types. On the one hand, speech reports that behave as syntactically independent clauses can feature indirect pronominal deixis. On the other hand, speech reports with a syntactically subordinate status - reported commands in the subjunctive - can feature direct pronominal deixis, as illustrated again in (45a) as opposed to (45b).

$$
\begin{array}{llllll}
\text { à } & \text { kó } & \text { ì } & \text { ní } & \text { ń } & \text { dèc̀màn } \\
\text { à } & \text { kó } & \text { ì } & \text { ni } & \text { ǹ } & \text { dècman } \\
\text { 3SG } & \text { say } & \text { 2SG } & \text { SBJV } & \multicolumn{2}{l}{\text { 1SG help }}
\end{array}
$$

'He said: You should help me.' (elicited)

$$
\begin{aligned}
& \text { à kó à náá dèc̀màn } \\
& \text { à kó à ni-à dècman } \\
& \text { 3SG say 3SG SBJV-3SG help } \\
& \text { 'Hei said that one should help himi.' (elicited) }
\end{aligned}
$$

\section{Conclusion}

This study presented a first account of speech reporting constructions in Kakabe. Our data confirms the idea that traditional treatments of reported speech fail to distinguish between two dimensions of cross-linguistic variation that are sharply demarcated in some African languages such as Kakabe. On the one hand, different constructions can be recruited for the expression of reported speech, and speech reports can be integrated structurally with the speech-event introducing part in a variety of different ways. The language-specific syntactic type of construction determines a number of structural properties of the speech reports, such as focus raising and prosody in Kakabe. On the other hand, languages differ in the way pronouns in speech reports are interpreted.

European languages tend to associate - at least in the formal registers - two different deictic strategies with different syntactic types of speech report: indirect deixis tends to appear in subordinate clauses, but direct deixis tends to be used in apposition-like speech reports. Even in European languages, however, deviations from the direct and indirect prototypes are common in colloquial speech (cf. Podlesskaya 2018 on colloquial Russian, Haberland 1986 on Danish). This suggests to us that even in European languages, a more precise characterization of the actually occurring strategies should treat separately the two dimensions currently subsumed under the terms direct and indirect speech.

Other languages provide more solid evidence for the dissociation of the two dimensions. For example, some may only allow one type of pronominal deixis (direct) to be used, independent of the construction's syntax. Others may allow for variation in pronominal deixis that is independent of the construction's structural properties. We have argued that Kakabe belongs to the latter type. Crucially, the indirect pronominal strategy is widely attested in 
Kakabe in constructions with syntactically non-subordinate speech reports, and the direct strategy is attested in reports that are syntactically subordinate.

Evidence that the choice of a pronominal strategy is independent, at least in some languages, of the syntax of the speech report has implications for theories of syntax that we cannot fully address in this study. It suggests that multi-dimensional constraint-based models of syntactic representation may be better equipped to handle the cross-linguistic variation in speech reporting strategies than the generative tradition of representing properties of pronominal deixis in configurational terms, by means of operators within the clause structure (Anand \& Nevins 2004; Shklovsky \& Sudo 2014, inter alia). This conclusion is supported by typological observations on the heterogeneous nature of subordination (Cristofaro 2003, 2014; Belyaev 2015), on the one hand, and by the non-universality of the principles underlying systems of pronominal deixis (Nikitina 2012b), on the other.

Finally, even though this study is based on data from just one language, the speech reporting strategies we have described for Kakabe may in fact be quite widespread in West Africa. We have pointed out in passim the affinity of this system with West African logophoric systems, and we believe that the affinity runs deep and deserves further study (Nikitina forthc.). Before further research sheds light on that relationship, we propose to treat the system described here for Kakabe as a type in its own right in the typology of speech reporting strategies: a type characterized by loose syntax with flexible indexicality.

$\begin{array}{llll}\text { Abbreviations } & & \\ \text { ART } & \text { referential article } & \text { NEG } & \text { negation } \\ \text { BNF } & \text { benefactive } & \text { OBL } & \text { Oblique } \\ \text { COP } & \text { copula } & \text { OF } & \text { operator focus } \\ \text { DIM } & \text { diminutive } & \text { POSS } & \text { possessive linker } \\ \text { DISC } & \text { discourse particle } & \text { PFV.I } & \text { perfective in intransitive clauses } \\ \text { EMPH } & \text { assertive emphasis marker } & \text { PFV.OF } & \text { perfective with operator (auxiliary) focus } \\ \text { FP } & \text { focus particle } & \text { PFV.TR } & \text { perfective in transitive clauses } \\ \text { FOC.C } & \text { focus of contrast } & \text { PL } & \text { plural } \\ \text { GER } & \text { gerund } & \text { PST } & \text { past } \\ \text { H\% } & \text { high boundary tone } & \text { QU } & \text { quotative } \\ \text { ID } & \text { identificational copula } & \text { SBJV } & \text { subjunctive } \\ \text { INTR } & \text { intransitive } & \text { SG } & \text { singular } \\ \text { ITJ } & \text { interjection } & \text { TR } & \text { transitive } \\ \text { LG } & \text { long form of personal pronoun } & & \\ \text { L\% } & \text { low boundary tone } & & \\ & & & \end{array}$

\section{References}

Aikhenvald, Alexandra. 2008. Semi-direct speech: Manambu and beyond. Language Sciences 30(4). 383-422. 
Anand, Pranav \& Andrew Nevins. 2004. Shifty operators in changing contexts. Semantics and Linguistic Theory 14. 20-37.

Belyaev, Oleg. 2015. Systematic mismatches: Coordination and subordination at three levels of grammar. Journal of Linguistics 51(2). 267-326.

Clark, Herbert H. \& Richard J. Gerrig. 1990. Quotations as demonstrations. Language 66(4). 764-805.

Coulmas, Florian (ed.) 1986. Direct and indirect speech (Trends in Linguistics. Studies and Monographs 31). Berlin: Mouton de Gruyter.

Connell, Bruce \& D. Robert Ladd. 1990. Aspects of pitch realisation in Yoruba. Phonology 7. $1-29$.

Cristofaro, Sonia. 2003. Subordination. Oxford: Oxford University Press.

Cristofaro, Sonia. 2014. Is there really a syntactic category of subordination? In Laura Visapää, Jyrki Kalliokoski \& Helena Sorva (eds.), Contexts of subordination: Cognitive, typological and discourse perspectives, 73-91. Amsterdam: John Benjamins.

D’Arcy, Alexandra. 2015. Quotation and advances in understanding syntactic systems. Annual Review of Linguistics 1(1). 43-61.

De Roeck, Marijke. 1994. A functional typology of speech reports. In Elisabeth EngbergPedersen, Lisbeth Falster Jakobsen \& Lone Schack Rasmussen (eds.) Function and expression in functional grammar, 331-351. Berlin: De Gruyter Mouton.

Evans, Nicholas. 2013. Some problems in the typology of quotation: A canonical approach. In Dunstan Brown, Marina Chumakina \& Greville G. Corbett (eds.) Canonical morphology and syntax, 66-98. Oxford: Oxford University Press.

Güldemann, Tom. 2008. Quotative indexes in African languages: A synchronic and diachronic survey. Berlin: Mouton de Gruyter.

Güldemann, Tom \& Manfred von Roncador (eds.). 2002. Reported discourse: A meeting ground for different linguistic domains. Amsterdam: John Benjamins.

Haberland, Hartmut. 1986. Reported speech in Danish. In Florian Coulmas (ed.) Direct and indirect speech, 219-254. Berlin: Walter de Gruyter.

Hyman, Larry M. \& Maria Polinsky. 2009. Focus in Aghem. In Malte Zimmermann \& Caroline Féry (eds.), Information structure, 206-233. Oxford: Oxford University Press.

Hyman, Larry M. \& John R. Watters. 1984. Auxiliary focus. Studies in African Linguistics 15. 233-273.

Idiatov, Dmitry. 2010. Person-number agreement on clause linking markers in Mande. Studies in Language 34(4). 832-868.

Klamer, Marian. 2000. How report verbs become quote markers and complementizers. Lingua 110. 69-98.

Kuteva, Tania, Bernd Heine, Bo Hong, Haiping Long, Heiko Narrog \& Seongha Rhee. 2019. World lexicon of grammaticalization. Cambridge University Press.

Lord, Carol. 1993. Historical change in serial verb constructions. Amsterdam: John Benjamins.

Malibert, Il-Il \& Martine Vanhove. (2015). Quotative constructions and prosody in some Afroasiatic languages: Towards a typology. In Amina Mettouchi, Martine Vanhove, \& Dominique Caubet (eds.) Corpus-based studies of lesser-described languages, 117-169. Amsterdam: John Benjamins. 
Matić, Dejan, Rik van Gijn \& Robert D. van Valin, Jr. 2014. Information structure and reference tracking in complex sentences: An overview. In Rik van Gijn, Jeremy Hammond, Dejan Matić, Saskia van Putten \& Ana Vilacy Galucio (eds.), Information structure and reference tracking in complex sentences, 1-42. Amsterdam: John Benjamins.

Matić, Dejan. 2014. Questions and syntactic islands in Tundra Yukaghir. In Rik van Gijn, Jeremy Hammond, Dejan Matić, Saskia van Putten \& Ana Vilacy Galucio (eds.), Information structure and reference tracking in complex sentences, 127-162. Amsterdam: John Benjamins.

McGregor, William B. (1994). The grammar of reported speech and thought in Gooniyandi. Australian Journal of Linguistics 14(1). 63-92.

Nikitina, Tatiana. 2009. The syntax of PPs in Wan, an "SOVX" language. Studies in Language 33(4). 907-930.

Nikitina, Tatiana. 2012a. Logophoric discourse and first person reporting in Wan (West Africa). Anthropological Linguistics 54(3). 280-301.

Nikitina, Tatiana. 2012b. Personal deixis and reported discourse: Towards a typology of person alignment. Linguistic Typology 16(2). 233-263.

Nikitina, Tatiana. 2018. When linguists and speakers do not agree: The endangered grammar of verbal art in West Africa. Journal of Linguistic Anthropology 28(2). 1-24.

Nikitina, Tatiana. 2019. Verb phrase external arguments in Mande: New evidence for obligatory extraposition. Natural Language \& Linguistic Theory 37(2). 693-734.

Nikitina, Tatiana. Forthc. Logophoricity and shifts of perspective: New facts and a new account. To appear in Functions of Language.

Nikitina, Tatiana \& Anna Bugaeva. Forthc. Logophoric speech is not indirect: Towards a syntactic approach to reported speech constructions.

Podlesskaya, Vera I. 2018. Čužaja reč v svete korpusnyx dannyx [Reported speech in light of corpus evidence]. Voprosy jazykoznanija 4. 47-73.

Roncador, Manfred von. 1988. Zwischen direkter und indirekter Rede. Tübingen: Niemeyer.

Saeed, John. 2004. The Focus Structure of Somali. In Brian Nolan (ed.) RRG 2004 Books of proceedings - Linguistic theory and practice: Description, implementation, and processing, 258-279. Dublin: Institute of Technology.

Shklovsky, Kirill, \& Yasutada Sudo. 2014. The syntax of monsters. Linguistic Inquiry 45(3). 381-402.

Spronck, Stef \& Tatiana Nikitina. 2019. Reported speech forms a dedicated syntactic domain: Typological arguments and observations. Linguistic Typology 23(1). 119-159.

Spronck, Stef. 2017. Defenestration: Deconstructing the frame-in relation in Ungarinyin. Journal of Pragmatics 114. 104-133.

Vydrina, Alexandra. A Corpus-based description of Kakabe, a Western Mande language: Prosody in grammar. Ph.D. dissertation, INALCO, 2017.

Yip, Moira J. W. 2002. Tone (Cambridge Textbooks in Linguistics). Cambridge: Cambridge University Press. 